\title{
First records of blue dragon Glaucus atlanticus Forster, 1777 (Gastropoda: Nudibranchia) in locations of Central Mexican Pacific
}

\begin{abstract}
Is reported for the first time in a scientific field, the presence of the nudibranch Glaucus atlanticus on some beaches of the Mexican central Pacific. Better known as Blue Dragon, this species initially only known in the Atlantic Ocean (hence its name), in recent years has expanded its geographic distribution to the extent considered now as a circum tropical species observed on the beaches around the world only in exceptional cases and representing weather conditions turn a nuisance for tourism by ascribing poisonous/stinging properties.
\end{abstract}

Keywords: Gastropods, molluscs, nudibrachs, pelagic, plankton
Volume 2 Issue 4 - 2018

\begin{abstract}
Victor Landa Jaime,' Mirella Saucedo Lozano,' Jesus Emilio Michel Morfin,' Monica Anabel Ortíz Arellano²

'Departamento de Estudios Para el Desarrollo Sustentable de Zonas Costeras, Universidad de Guadalajara, Mexico

${ }^{2}$ Facultad de Ciencias del Mar, Universidad Autónoma de Sinaloa, Mexico
\end{abstract}

\begin{abstract}
Correspondence: Victor Landa Jaime, Departamento de Estudios Para el Desarrollo Sustentable de Zonas Costeras, Universidad de Guadalajara, Gómez Farías 82, San Patricio, Melaque, Jalisco, Mexico, Tel 01315355 6330,

Email victor.landa@academicos.udg.mx
\end{abstract}

Received: May 24, 2018 | Published: July 20, 2018

\section{Introduction}

Glaucus atlanticus Forster, 1777, is a holopelagic nudi branch mollusk known in many parts of the world as Blue Dragon and usually live in ocean waters in the water-air interface, part of pleuston. ${ }^{1}$ One of the most notable features of this species, in addition to its beauty, it is that feeds on the Hydrozoa Cnidarians gender Physalia, Velella and Porpita. Which as all members of the phylum, have poisonous cells called cnidocyte or nematocysts and characterized by stay floating on the ocean surface and are carried by currents.

The ability to be immune to venom prey and the particularity of the toxic effect of enhancing such cells, dragon blue often incorrectly perceived as one of the most poisonous opistobranquios planet. It can be an inconvenience for beach tourism, where in certain seasons of the year is approaching the coastal areas washed away by currents and winds can cause skin lesions. Although Glaucus atlanticus presents a cosmopolitan geographical distribution in warm and temperate zones, published scientific information about the species is very rare in the Mexican and Central Pacific, where the bibliographical sources can be summarized a few items. ${ }^{2,3}$ A recent molecular study on pelagic nudibrachs showed that Glaucus marginatus (Reinhardt and Bergh, 1977 ) is a complex of three cryptic species, whereas the congener G. atlanticus is a single species. ${ }^{4}$ Although this species is relatively well known, most of the existing information is reporting sightings informally on several beaches in the world by tourists or local institutions of civil protection.

\section{Results}

In this paper, their presence on several beaches on the coastline of Central Mexican Pacific through recent data (Figure 1) diffuses.

\section{Incidence localities}

During 2016-2017: Mazatlán, Sinaloa $\quad\left(23^{\circ} 15^{\prime} 08^{\prime}\right.$ N $\left.106^{\circ} 24^{\prime} 42^{\prime \prime} \mathrm{W}\right)$; Punta Mita, Nayarit (2046’46”N; 105³1’38”W); Puerto Vallarta, Jalisco $\left(20^{\circ} 39^{\prime} 18^{\prime \prime} \mathrm{N}\right.$; $\left.105^{\circ} 13^{\prime} 34^{\prime \prime} \mathrm{W}\right)$; Punta Perula, Jalisco (19 $\left.36^{\prime} 16^{\prime \prime} \mathrm{N} ; 105^{\circ} 09^{\prime} 30^{\prime \prime} \mathrm{W}\right)$; Tenacatita, Jalisco (19¹6'59”'N; $\left.104^{\circ} 52^{\prime} 27^{\prime \prime} \mathrm{W}\right)$; Manzanilla, Jalisco $\left(19^{\circ} 17^{\prime} 05^{\prime \prime} \mathrm{N}\right.$; 1044ㄱ'13”W); Bahía de Navidad, Jalisco (1906’00”N; 104¹9'59”W); Manzanillo,

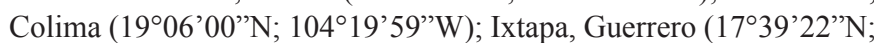
$\left.101^{\circ} 53^{\prime} 29^{\prime \prime} \mathrm{W}\right)$. In all cases, its presence was associated with strong winds dominant from north to south in the months of May and July.

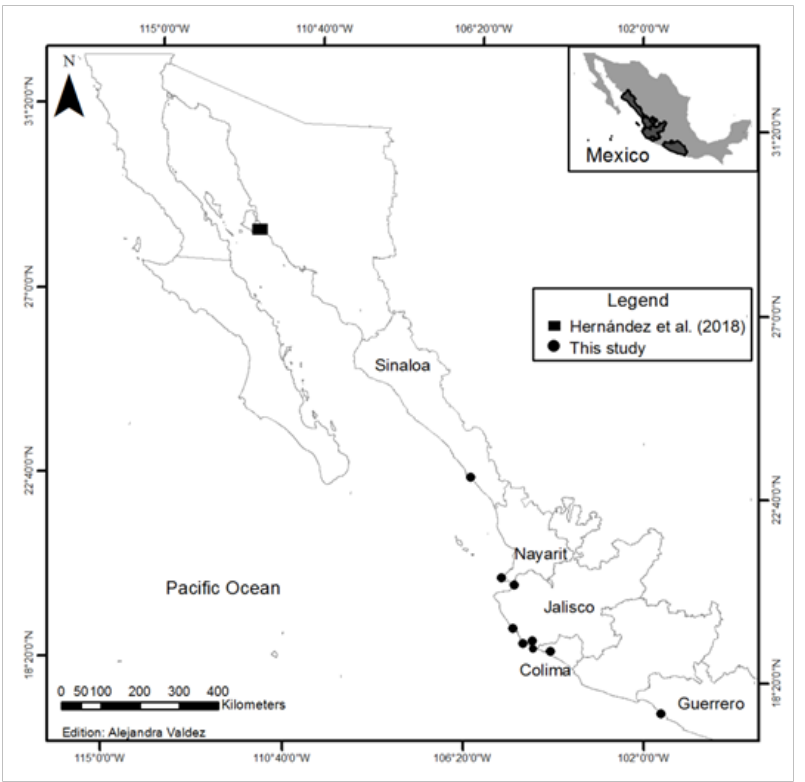

Figure I Study area where indicate localities with presence of Glaucus atlanticus in this study and Hernández et al., ${ }^{6}$ in the Mexican Central Pacific. 


\section{Material examined}

It consists of the capture of three bodies on Bahía de Navidad, Jalisco, by the use of surface plankton nets in July 2016 and manual collection of 25 organisms on the beach in Mazatlan, Sinaloa, in May 2017 and sighting during those two years in six beaches, corresponding to four states in the Central Mexican Pacific (Figures 2 to Figure 4).

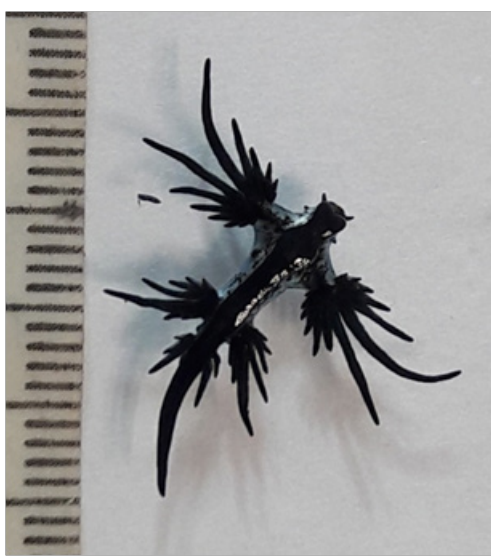

Figure 2 Glaucus atlanticus dorsal view. (Photo by MA Ortíz-Arellano).

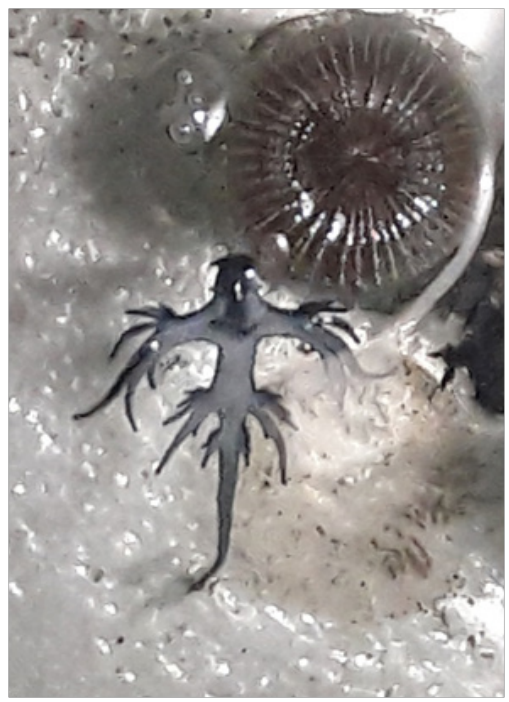

Figure 3 Glaucus atlanticus (ventral view) and Porpyta sp. (Photo by MA OrtízArellano).

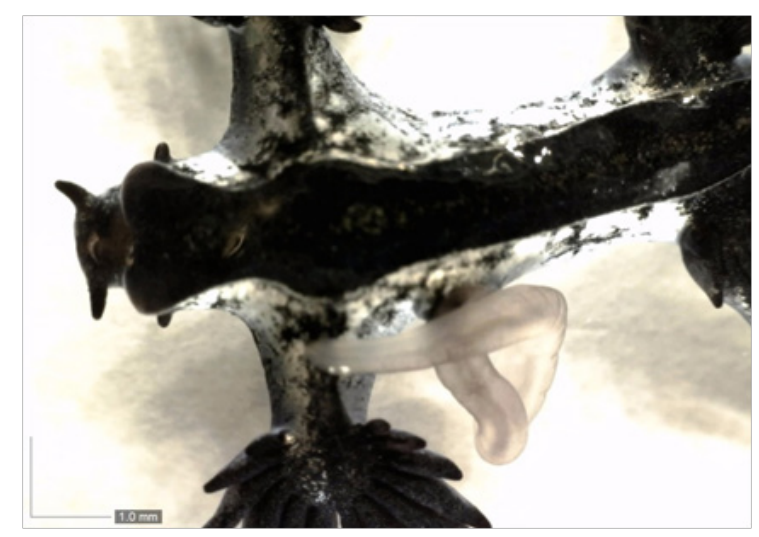

Figure 4 Glaucus atlanticus and his penis (dorsal view). (Photo by MA OrtízArellano).

\section{Discussion}

In previous paragraphs have commented that studies aimed at understanding the biology and habits of this species are considered relatively rare for being an ocean and wandering species. In contrast, there are advanced studies describing the molecular systematics and morphometric this complex specie ${ }^{5}$ and exist a wide genetic information of the species in the NCBI Gen Bank.

A recent study by using molecular analysis, determine that $G$. atlanticus from the Gulf of California is related to specimen from the North and South Pacific Oceans, suggesting a high potential for dispersal during the larval and adult stage. ${ }^{6}$ Moreover, same authors report that specimens of $G$. atlanticus have been recorded in others localities of East Pacific as well, but "there are no recent records for G. marginatus since the publication by Thompson and McFarlane (1967)". ${ }^{6}$ Finally, it highlights the fact that there are still gaps in information about these species.

\section{Acknowledgments}

The authors wish to express their gratitude to Alejandra Valdez Cibrian for the preparation of the map.

\section{Conflict of interests}

Author declares that there is no conflict of interest.

\section{References}

1. Valdez A, Campillo OA. Systematic of Pelagic aeolid Nudibranchs of the Family Glaucidae (Mollusca, Gastropoda). Bulletin of Maine Science. 2004;75(3):381-389.

2. Segovia J, Lopez G. Record of Glaucus atlanticus from El SalvadorPacific Coast of Centro America. Revista Mexicana de Biodiversidad. 2015;86(4):1089-1090.

3. González-Duarte M, Cervera JL, Poddubetskaia M. Description of a new northeastern Atlantic aeolid of the genus Flabellina (Mollusca, Nudibranchia). Bulletin of Marine Science. 2008;82(1):33-39.

4. Churchill KC, Valdes AB, Foighil DO. Molecular and morphological systematics of neustonic nudibranchs (Mollusca: Gastropoda: glaucidae: Glaucus), with descriptions of three new species cryptic. Invertebrate Systematics. 2014;28(2):174-195.

5. Churchill CK, Alejandrino A, Valdez A. et al. Parallel changes in genital morphology delineate cryptic diversification of planktonic nudibranchs. Proc Biol Sci. 2013;280(1765): 20131224.

6. Hernández L, Munguía-Vega A, Pérez-Alarcón F, et al. Ocurrence of Glaucus atlanticus in the Midriff Islands region, Gulf of California, Mexico. Amer Malac Bull. 2018;36(1):145-149. 